\title{
L2 Anxiety, Self-Regulatory Strategies, Self-Efficacy, Intended Effort and Academic Achievement: A Structural Equation Modeling Approach
}

\author{
Huei-Ju Shih ${ }^{1}$ \\ ${ }^{1}$ The Department of English, National Changhua University of Education, Changhua, Taiwan, R.O.C. \\ Correspondence: Huei-Ju Shih, The Department of English, National Changhua University of Education, \\ Changhua, Taiwan, R.O.C. Tel: 886-935-580-868. E-mail: beckeystone@gmail.com
}

Received: October 14, 2018

Accepted: November 19, 2018

Online Published: February 26, 2019

doi:10.5539/ies.v12n3p24

URL: https://doi.org/10.5539/ies.v12n3p24

\begin{abstract}
Factors that contribute to learning achievement have always been a primary research concern in the field of education. In the field of second/foreign language (L2) learning, researchers have been trying to explore many important factors that are linked to successful learning and how these factors may predict the success of language learning. With respect to the factors contributing to language proficiency, many researchers endeavor themselves to the exploration of assisting the learners. The present study aims to explore whether or not the following factors would influence learners' academic achievement: the process of goal-setting, the L2 anxiety, the effort the learners put into, self-efficacy together with self-regulatory strategies. A total number of 356 senior high school students who were learning English as a Foreign Language participated in the study. A new questionnaire was developed to measure and collect the participants' responses in respect to the above-mentioned learning factors. In order to investigate the relationships among these factors and the learners' academic performance, the structural equation modeling (SEM) was used to identify the best fit model. It was found that self-efficacy, L2 anxiety, together with goal-setting processes, are prerequisites for the application of effective self-regulatory strategies, which in turn play an important role in affecting the intended efforts the learners make, and consequently influence the learners' achievement. According to the findings, we suggest the teacher elevate the students' self-efficacy, lower the L2 anxiety, help set their learning goals, cultivate their capability of employing strategies and increase their intended effort.
\end{abstract}

Keywords: L2 anxiety, self-efficacy, self-regulatory strategies, structural equation modeling

\section{Introduction}

With increasing attention given to improve language learners' performance, educators leave no efforts to work out a better way to assist the learners. The factors related to individual differences count as important in influencing learners' academic performance. The L2 anxiety, self-efficacy, self-regulatory strategies, together with the goal-setting theory have been considered to play significant roles in successful language learning. Among the factors, language anxiety, which is negatively correlated with language achievement (Gardner et al., 1997), is thought to be the most powerful predictor on the students' performance (Liu \& Huang, 2011). Self-efficacy is individual belief in their ability to perform a certain task (Bandura, 1977). For language learners, they form and adjust their self-efficacy beliefs by deliberately evaluating their mastery and vicarious experiences, verbal messages and their own emotional states when communicating with others (Bandura, 1986; Usher, 2009). Goal-setting helps to enhance a learner's self-efficacy and also has an impact on learners' self-regulation behaviors (Bandura, 1997; Schunk, 1995). The influence of these factors on learners' academic performance has been extensively researched. However, few studies have examined the relationships among these aforementioned factors.

Perceived self-efficacy, according to Bandura (1994), is "people's belief about their capabilities to produce designated levels of performance that exercise influence on events affecting people's lives." That is, the higher level of self-efficacy one perceives, the higher possibility challenging tasks is taken. When it comes to the sources of self-efficacy, mastery experiences, vicarious experiences, verbal persuasion and emotional states (Bandura, 1977, 1997; Usher \& Pajares, 2008) are the key elements. Mastery experience refers to continuous 
efforts put into the process of pursuing success. The sustained efforts build a sense of efficacy, making the individual convinced that they can control their learning and help them become tougher from adversity (Bandura, 1977, 1997). Vicarious experiences come from watching the people similar to oneself succeed or fail. Others' experience contributes to raise their beliefs or reduce their confidence. The extent of the influence lies in the level of similarities between the model and the individual. If the individual is very similar to the model, the influence is strong. On the other hand, for a model who is very different from the individual, the influence is not so much (Bandura, 1997). Verbal persuasion is a third source of influencing people's perceived self-efficacy. Compliments may make people believe that they possess the capabilities to master activities. They are likely to make greater efforts and show more persistence in the face of difficulties. On the other hand, people who receive negative comment may lack confidence tend to avoid challenging tasks. For successful efficacy builders, they not only try to raise people's confidence but also avoid failure (Bandura, 1997). The final source is about emotional states. Positive mood enhances self-efficacy, but negative one diminishes it (Bandura, 1997).

In addition, self-efficacy influences human function in four aspects: cognitive, motivational, affective, and selection processes (Bandura, 1993). In cognitive processes, if the perceived self-efficacy is strong, people are more likely to set challenging goals and demonstrate firm commitment to the goals. Besides, imagery vision also plays a significant role in the personal beliefs. People with a high sense of self-efficacy can visualize success and devote more efforts. On the other hand, people with a weak sense of self-efficacy visualize failure and doubt themselves.

A second aspect is the motivational processes. Three forms of cognitive motivators build this aspect. They are causal attributions, outcome expectancies and cognized goals, which respectively correspond to attribution theory, expectancy-value theory and goal theory. Causal attribution refers to the fact that those people with high efficacy often attribute their failures to insufficient efforts. Expectancy-value theory means that people act on their beliefs about what they can do, and they assess possible outcomes based on the beliefs. Goal theory demonstrates that explicit, challenging goals enhance and sustain motivation. In short, self-efficacy beliefs contribute to motivation. The beliefs determine what goals people set, how much effort they expend, how long they sustain in face of difficulties and how they react to failures (Bandura, 1993).

The third aspect is affective processes. In affective processes, negative feeling such as stress, depression and anxiety has an influence on the intensity of perceived self-efficacy. Those who can put the negative feeling under control can manage difficult situations and reduce anxiety along with avoidant behaviors (Bandura, 1993).

The last one is selection processes. What choice people make will represent their perceived self-efficacy. Take the career for example. People with high perceived self-efficacy consider a wider range of career. They make better preparation for the work and have a greater chance of success (Bandura, 1993).

The focus of the present study is to examine whether the L2 learners' self-efficacy acts as the predictor of the language achievement. Therefore, the language learners' self-efficacy on the four skills-listening, speaking, reading, and writing along with the overall skills are under evaluation. The instrument is partly adapted from Piniel and Csizer (2013), which offers items from the four skills.

Horwitz, Horwitz, and Cope (1986) first proposed the idea that foreign language anxiety (FLA) is a unique type of anxiety specifically appearing in the foreign or second language learning context. They claimed that FLA is "a phenomenon related to but distinguishable from other specific anxieties" (p. 129). They pointed out that foreign language anxiety falls into three categories: communication apprehension, fear of negative evaluation, and test anxiety. This model becomes a dominant one and then based on this definition several researchers create their own definitions about foreign language anxiety.

For example, Clement (1980) designated FLA as a complex construct dealing with learners' mental activities with respect to feelings, self-esteem, and self-confidence. In addition, Young (1992) specified it as a complicated psychological phenomenon with the emphasis on its distinctive features. Moreover, MacIntyre and Gardner (1994b) elucidated FLA as the feeling of stress and apprehension aroused in speaking, listening, and learning, or the worry and negative emotional reaction (MacIntyre, 1999). Likewise, Zhang (2001) defined anxiety as the psychological tension that the learner undergoes in performing a task. Dörnyei (2005) proposed that foreign language anxiety involves different types. Among them, two of the most well-known regimentations are trait/state (Speilberger, 1983) and facilitating/debilitating (Scovel, 1978) views of anxiety. Trait anxiety stays stable over time, whereas state anxiety is a momentary feeling. Facilitating anxiety could improve performance and have a positive impact on leaning. On the other hand, debilitating anxiety has a negative effect.

In terms of the instrument to assess FLA, Horwitz, Horwitz, and Cope (1986) established a 33-item questionnaire, called Foreign Language Classroom Anxiety Scale (FLCAS) to measure language anxiety. On the 
basis of this, a plethora of studies have been conducted on language anxiety. The results are inconsistent. Some studies have shown a positive relationship between language anxiety and language achievement (e.g., Liu, 2006; Oxford, 1999), whereas most of others have shown that language anxiety is negatively related to language achievement (e.g., MacIntyre, 1999; Horwitz, 2001; MacIntyre, Noels, Clement, 1997). That is, the more proficient learners get, the less anxiety they experience. Horwitz (2010) explained the confusing results was due to the multi-faced conceptualization of anxiety. Many researchers still have doubt about the specificity of L2 anxiety. For example, MacIntyre (1989) and Aida (1994) questioned that test anxiety is a general anxiety problem, which is opposed to the concept that L2 anxiety is specific. With respect to the FLCAS scale, Sparks and Ganschow $(1991,1996,2007)$ have interrogated the validity of the scale and maintained that the scale measures language skills, not L2 anxiety levels. They have also criticized the FLCAS excludes native language skills or foreign language aptitude. Because the present study explores several latent variables, each of which contains several items of questions. To save the time on answering the questionnaire, Papi's (2010) scale was adopted, which includes only six items to evaluate the L2 anxiety.

In research on motivation, goal setting plays a vigorous role. Locke (1968) stated that employees were motivated by specific goals and appropriate feedback. Furthermore, working toward a goal provided a major source of motivation to actually reach the goal-which, in turn, enhanced performance. Locke further revealed that a relationship existed between a goal and people's performance. That is, specific and difficult goals led to better performance than vague or easy goals. Locke and Latham (1990) emphasized the need to set specific and difficult goals for better performance. In setting goals, challenging goals are a better alternative, and sustained efforts will activate to achieve goals. If a person fails, it is because of the insufficient efforts or deficient knowledge.

Goal setting can be effectively used to numerous domains. The success of goal setting counts upon taking consideration of the mediators and moderators with regards to efficacy and applicability. Locke and Latham (2006) maintained that four mediators are between goals and performance: (1) Compared with moderately difficult, easy, or vague goals, high goals lead to greater effort and/or persistence. (2) The function of goals is to direct attention, effort, and action toward goal-relevant behaviors. (3) The requisite task knowledge and skills affects the effects of goals. (4) Goals may stimulate one to use potential ability, stored relevant knowledge, and search for new knowledge. Locke and Latham (1990) also stressed that the key moderators of goal setting are (1) feedback, which aids people to trace their progress; (2) commitment to the goal, which is strengthened by self-efficacy and taking the goal as important;(3) task complexity, that task knowledge is hard to acquire; and (4) situational constraints, which means the goal will be modified according to the situation.

In their article, Locke and Latham (2006) further pointed out that a learning goal boosts or increases metacognition - namely, planning, monitoring, and evaluating progress toward goal realization. The findings in Brown et. al (2005) supported the concept that goals affected performance only when overload was low. Goals can be allocated by others, be set jointly with others, and be self-set. In the self-set goals, self-regulation is the key to accomplish the goals. Since the questionnaires for goal setting are usually in the form of open questions, which make it hard for the quantified evaluation. Therefore, the researchers developed a 7-point Likert scaled questionnaire for the ease of quantifying the responses from the participants. The validity and reliability has been tested to reach the criteria before distributing to the respondents.

For a long time, SLA research on learning strategies focused largely on how learning strategies were applied in the procedure of achieving language learning goals (e.g., O'Malley \& Chamot, 1990; Oxford, 1990). There are some conundrums on language learning strategies research: the ambiguous definition, and the assessment instrument (e.g. Ellis 1994; Skehan 1989; Dörnyei \& Skehan 2003). Self-regulation is a course during which people organize, and manage their learning behavior. Dörnyei (2005) argued for the need to conduct research on the process of how learners perform control over their learning. Winne and Perry (2000) claimed that the nature of self-regulating capacity is about an aptitude. In addition, it is teachable and can be influenced by experience:

Self-regulated learning is now modeled as a "developable" aptitude - an aptitude that changes incrementally with experience and instruction - for dynamically adapting how one changes with tasks. (Winne, 1996, p. 330)

Therefore, learners' former learning experience may influence learners' developmental level of self-regulating potential. Self-regulation of learning includes learners setting their learning goals, selecting appropriate strategies, retaining motivation, and monitoring and appraising academic progress (Zimmerman, 2000). This takes learners' capabilities to control over their thoughts, emotions, behaviors as well as the learning context. Thoughts means the competency beliefs; emotions include anxiety aroused while learning; behaviors refers to how people cope with a learning task; learning context is the surroundings of learning (Pintrich \& De Groot, 1990; Zimmerman, 1998). The motivation can be consciously regulated and observed. The concept of self-regulation has a lot in common with self-determination theory. Reeve et al. (2008) claims that "autonomous 
self-regulation is associated with autonomous motivation and is characterized by a sense of volition and choice" (p. 225). For self-regulated learning strategies, Pintrich (2004) proposed four classifications: (a) learners are energetically establishing meaning, setting goals, and deciding strategies; (b) learners have the ability to control their learning; (c) the strategies are not random but goal-oriented; and (d) the strategies reconcile the relationship between personal and environmental characteristics and achievement or performance. Likewise, Kuhl (1985) suggests six action-control strategies, and they can be categorized into four subsets- (a) controlling cognition, including attention strategies, encoding strategies, and information control strategies; (b) controlling motivation-incentive-escalation strategy;(c) emotional control strategies and (d) environmental strategies. Besides, Corno \& Kanfer (1993) evaluated related research and then divided volition strategies into two types - covert strategies and overt ones. Covert strategies include (a) metacognition control, (b) motivation control and (c) emotion control. Overt strategies are related to control; they contain (a) control the task situation and (b) control others in the task setting.

On the basis of the taxonomies of Kuhl (1985) and Corno \& Kanfer (1993), Dornyei (2001) puts forward a new theoretical conceptualization of self-regulation strategies in SLA. Five types of control strategies are categorized. They are (a) commitment control, which stipulates goal commitment; (b) metacognitive control, which aids learners maintain attention; (c) satiation control, which helps lessens the feeling of boredom; (d) emotional control, referring to emotional management;(e) environmental control, helping learners create an appropriate context for study. Furthermore, the empirical study conducted by Tseng, Dornyei \& Schmitt (2006) provided support for the validity of Dornyei's (2001) taxonomy. Tseng et. al (2006) recommend a new approach of a L2 learners' strategic learning to be an alternative to the traditional scales used to quantify language learning strategy use. Tseng applied the measurement to different studies (e.g., Tseng, 2008; Tseng, 2017) and found the scale could attain high reliability and strong validity. Hence, the present study employed this measurement to assess the participants' self-regulatory strategies in L2 learning.

\section{Method}

\subsection{Purpose of the Study}

Based on the theoretical considerations, a hypothesized model is constructed and tested in order to confirm the relationships among L2 anxiety, self-efficacy, self-regulatory strategies, goal-setting, intended effort and the academic achievement. The hypotheses are formulated as follows:

H1: L2 anxiety can predict the results of self-efficacy, goal-setting strategies and self-regulatory strategies.

$\mathrm{H} 2$ : Goal-setting is a significant predictor of self-regulatory strategies and then influences academic performance.

H3: Self-regulatory strategies are positively related to academic performance.

H4: Intended effort functions as a mediator in the process that self-efficacy and self-regulatory strategies exert their influences on academic performance.

\subsection{Participants}

The sample consisted of 356 senior high school students who were learning English as a foreign language in Taiwan, with 198 males and 158 females, 15-19 years of age. The participants all speak Mandarin Chinese as their first language. They had been studying English since 10 years old. English is an important subject not only because it is a compulsory school subject to the participants but also a subject of the entrance college examinations, which is a general situation in Taiwan.

\subsection{Instrument}

The instrument used in this study involved a self-report questionnaire focusing on the motivational measures based on Papi (2010) for L2 anxiety, Piniel \& Csizer (2013) for self-efficacy, Tseng et al. (2006) for self-regulatory strategies and goal setting created by the researcher tailed for the participants in this study. The questionnaire contains 607 -point Likert type items ranging from 1=strongly disagree to $7=$ strongly agree. The internal consistency coefficients of the scales range from .81-.95, which indicates a satisfying reliability of the questionnaire. Table 1 presents the Cronbach Alpha value, number of items and the sample item of each subscale.

(1) Self-efficacy: 14 items from Piniel, \& Csizer(2013)

(2) L2 anxiety: 6 items from Papi (2010),

(3) Goal setting: 14 items 
(4) Self-regulatory strategies: 26 items basically from Tseng et al. (2006)

The items were originally used for evaluating the learners' strategies in learning English vocabulary. However, in this study, the researcher modified the description into evaluating the participants' strategies for learning overall English.

(5) Intended efforts: 6 items, adapted from Taguchi et. al. (2009)

(6) Academic performance: four categories, including vocabulary, cloze tests, filling-in, and reading comprehension presented in the form of multi-choice

Table 1. Reliability coefficients, numbers of items and sample items the subscales

\begin{tabular}{|c|c|c|c|}
\hline Subscales & $\begin{array}{l}\mathrm{N} \text { of } \\
\text { items }\end{array}$ & $\begin{array}{l}\text { Cronbach } \\
\text { Alpha }\end{array}$ & Sample item \\
\hline Self-efficacy(reading) & 2 & .86 & I believe that I can read English silently well in class. \\
\hline Self-efficacy(speaking) & 2 & .86 & I am confident that I can speak English well in class. \\
\hline Self-efficacy(writing) & 2 & .83 & I am thinking that I can write a good English composition in class. \\
\hline Self-efficacy(listening) & 2 & .87 & I understand the English listening questions and answer them right in class. \\
\hline $\begin{array}{l}\text { Self-efficacy } \\
\text { (overall feeling) }\end{array}$ & 6 & .95 & I am confident that I can complete tasks well in English class. \\
\hline L2 anxiety & 6 & .95 & If a foreigner asked me for direction in English, I would feel nervous. \\
\hline $\begin{array}{l}\text { Goal setting } \\
\text { (learning goals) }\end{array}$ & 5 & .90 & I would set specific goals for my learning. \\
\hline $\begin{array}{l}\text { Goal setting } \\
\text { (task strategy) }\end{array}$ & 3 & .87 & My goals will be compared with my progress. \\
\hline $\begin{array}{l}\text { Goal setting } \\
\text { (feedback) }\end{array}$ & 2 & .83 & Encouraging remarks from others is important for me. \\
\hline $\begin{array}{l}\text { Goal setting } \\
\text { (task complexity) }\end{array}$ & 4 & .89 & Complex projects will be broken down into small tasks. \\
\hline $\begin{array}{l}\text { Self-regulatory } \\
\text { strategies } \\
\text { (situational) }\end{array}$ & 4 & .86 & $\begin{array}{l}\text { Once the fresh feeling of learning a new grammar/word disappears, I become } \\
\text { impatient. }\end{array}$ \\
\hline $\begin{array}{l}\text { Self-regulatory } \\
\text { strategies } \\
\text { (emotional) }\end{array}$ & 4 & .84 & When I feel stressed about learning English, I know how to overcome this feeling. \\
\hline $\begin{array}{l}\text { Self-regulatory } \\
\text { strategies } \\
\text { (environmental) }\end{array}$ & 4 & .86 & $\begin{array}{l}\text { While I am studying English and the learning place becomes unsuitable, I know } \\
\text { how to solve the problem. }\end{array}$ \\
\hline $\begin{array}{l}\text { Self-regulatory } \\
\text { strategies } \\
\text { (commitment) }\end{array}$ & 4 & .88 & When I am learning English, I have personal techniques to achieve my goals. \\
\hline $\begin{array}{l}\text { Self-regulatory } \\
\text { strategies } \\
\text { (metacognitive) }\end{array}$ & 4 & .87 & When learning English, I know how to stay focused on my study. \\
\hline $\begin{array}{l}\text { Self-regulatory } \\
\text { strategies } \\
\text { (skill mastering) }\end{array}$ & 6 & .93 & When in English class, I volunteer to answer as much as possible. \\
\hline intended efforts & 6 & .93 & I am ready to put a lot of effort into learning English. \\
\hline Academic performance & 4 & .81 & $\begin{array}{l}\text { four categories, including vocabulary, cloze tests, filling-in, and reading } \\
\text { comprehension presented in the form of multi-choice }\end{array}$ \\
\hline
\end{tabular}

For the academic performance part, the question number of each category is ten, with a total number of 40 questions on the test paper. In the process of coding the questionnaire, the number " 1 " means the learner answer one question right; " 10 " means the learner answers 10 questions right. This scale of academic performance can be regarded as a 10-point scale with four categories. The Cronbach Alpha $(\alpha)=0.81 \geq 0.7$ is considered acceptable. 
The English version of the questionnaire was translated into Mandarin Chinese by the author and was then edited by a teacher who taught Chinese literature. Before administering it to the students in the main study, the questionnaire was piloted among 102 students other than the participants in the main study.

Data Collection and Analysis:

The participants were informed that the survey was only for academic research and their reply would not influence their grades. The students spent approximately 20 to 25 minutes completing the questionnaire. The part of academic performance was executed one week after the participants finished the previous section of questionnaire on individual differences. This test was held simultaneously at different classes with the homeroom teachers monitoring them. It took 50 minutes to answer the test. The data were coded in AMOS 23.0 version.

The Hypothesized Model:

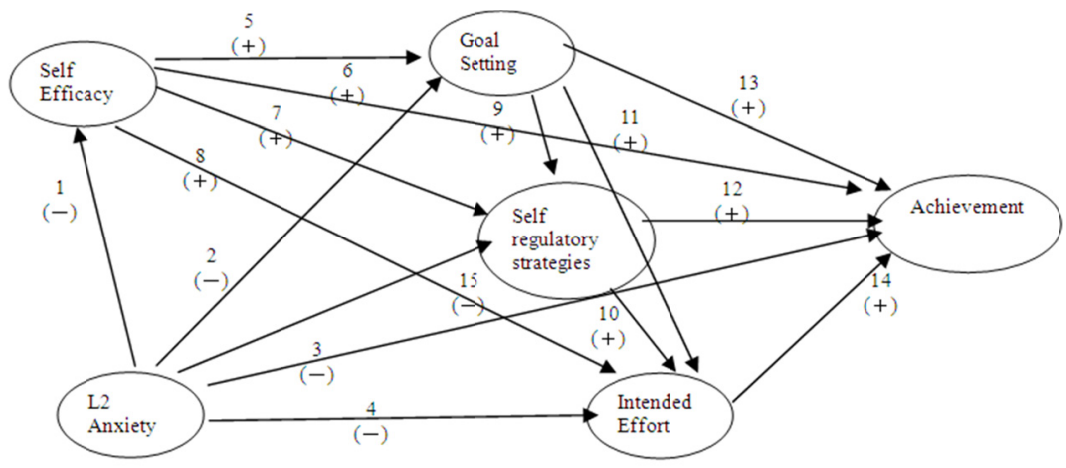

Figure 1. The hypothesized model of six latent variables

Based on the aforementioned discussion, the six latent variables and the hypothesized relationships among them form a model as the above figure. The hypothesized paths between variables are given a number. A "+" sign or a "-_"sign indicates a positive influence or negative influence in a particular path. Note that the paths connected to L2 anxiety are hypothesized as negative, whereas others are hypothesized as positive.

\section{Results}

\subsection{Model Evaluation}

Table 2 revealed the results of model evaluation. They support the acceptability of the hypothesized model.

Table 2. Model fit indexes for the hypothesized model

\begin{tabular}{llllccccc}
\hline Model fit indexes & & & & & & & & \\
\hline & X2/df & GFI & AGFI & CFI & TLI & IFI & NFI & RMESA \\
\hline Acceptable fit & $<3$ & $>.9$ & $>.9$ & $>.9$ & $>.9$ & $>.9$ & $>.9$ & $.05<\mathrm{x}<.08$ \\
\hline Hypothesized model & 1.90 & .90 & .89 & .98 & .98 & .98 & .96 & .053 \\
\hline
\end{tabular}

The chi-square/df ratio $(\mathrm{x} 2=799.95, \mathrm{df}=421, \mathrm{p}<.01)$, the goodness-of-fit index (GFI), the comparative fit index (CFI), the Tucker-Lewis index (TLI), the incremental fit index (IFI), the normal fit index (NFI), and the root mean square error of approximation (RMESA) all reached or exceed acceptable fit thresholds. The only one fit index that did not meet the acceptable thresholds (adjusted goodness-of-fit index [AGFI]) also approached the threshold. It is normal for some indexes to not conform to the majority trend in SEM, so the hypothesized model had a good overall fit with the empirical data. The results were presented in Figure 2. 


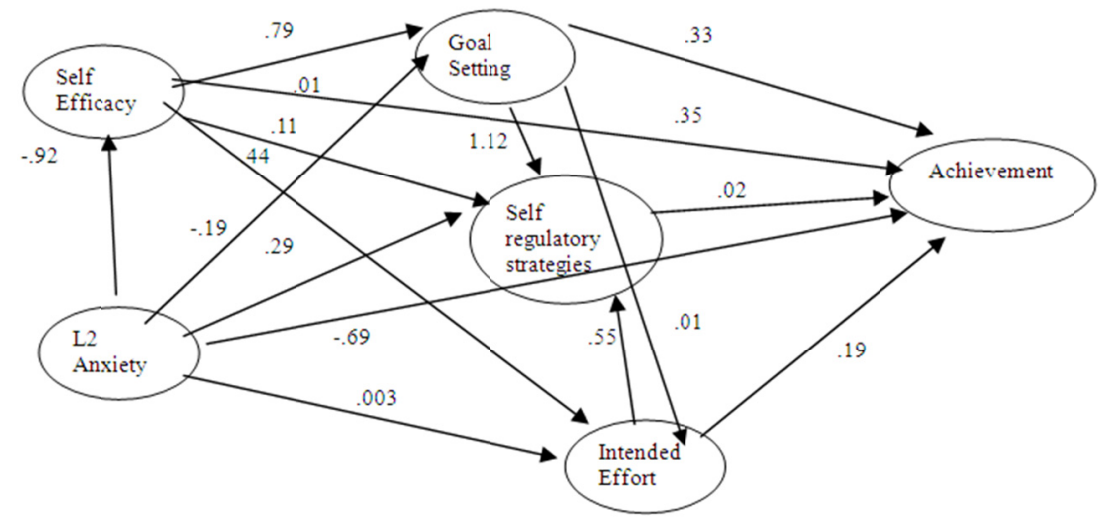

Figure 2. The results of the hypothesized model

A further examination of the strengths of the causal relationships among the six latent variables, several improvements were necessary for the hypothesized model (Figure 2). The causal relationship for self-efficacy with self-regulatory strategies (Path 7, the critical ratio (C.R.) absolute value is $0.528, p>.05$ ) does not reach the significantly different level. Likewise, the causal relationships for L2 anxiety toward intended effort (Path 4, C.R. absolute value $=0.144, p>.05$ ), intended effort over achievement (Path 14, C.R. value $=0.515, p>.05$ ) and self-efficacy over achievement (Path 6, C.R. value $=0.965, p>.05$ ) were not strong enough to reach the significant level. So these paths were eliminated from the model. The results of the finalized model were shown in Figure 3.

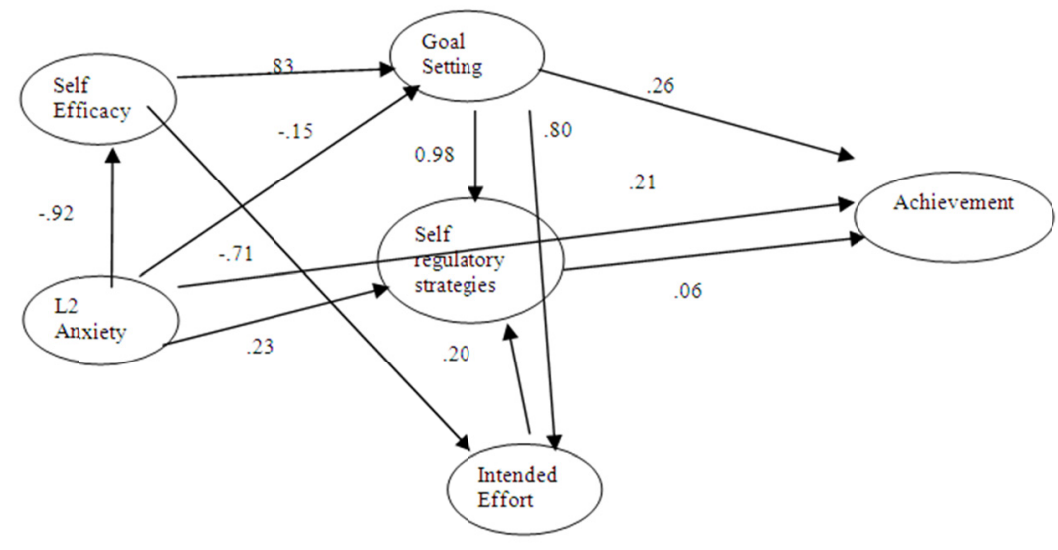

Figure 3. The results of the finalized model

Table 3. Model fit indexes for the finalized model

\begin{tabular}{lllllllll}
\hline Model fit indexes & \multicolumn{1}{l}{} & & & & & & & \\
\hline & X2/df & GFI & AGFI & CFI & TLI & IFI & NFI & RMESA \\
\hline Acceptable fit & $<3$ & $>.9$ & $>.9$ & $>.9$ & $>.9$ & $>.9$ & $>.9$ & $.05<\mathrm{x}<.08$ \\
\hline Finalized model & 1.86 & .91 & .92 & .98 & .98 & .98 & .96 & .052 \\
\hline
\end{tabular}

\section{Discussions}

The results indicated that the level of L2 anxiety has a great impact on the following latent variables: self-efficacy, self-regulatory strategies, goal-setting process, and academic achievement. All of the aforementioned variables are negatively correlated with the L2 anxiety. This demonstrates that the more anxiety a language learner feels, the less self-efficacy one has, the fewer self-regulatory strategies one will exert, the less motivated in the process of setting personal goals to achievement, and therefore makes personal performance worse or failing to live up to the expectations. For the intended effort, the result showed that there is no 
significant relationship between L2 anxiety and intended effort. This indicates that however anxious a language learner may be, the effort one put forward will not be diminished.

In terms of the role of self-efficacy, it directly predicts the strength of learners' goal-setting process. With the mediator of goal-setting, it indirectly influences learners' academic performance as well as the self-regulatory strategies. The results indicate that the more self-efficacy a language learner holds, the more likely the goal-setting process can be carried out. Moreover, the more self-efficacy one possesses, the better the academic performance is. The findings are consistent with previous research which examines the relationship between goal setting and self-efficacy (Bailey, 1999; Cheung \& Cheng, 1997; Schunk, 1991; Schunk \& Zimmerman, 1997). In addition, the strength of self-efficacy contributes to the self-regulatory strategies one will manipulate. Furthermore, the level of self-efficacy has a connection with the intended effort one exerts. It means that more efficacious language learners put more efforts in learning a target language, and therefore achieve success. This finding is in line with previous studies (e.g., Bandura, 1997; Pajares \& Urdan, 2006; Zimmerman, 2000).

In the present study, self-efficacy serves as the prerequisite of goal-setting. The relationship is positive. This is in line with Carroll et al. (2013). In the current study, the result shows that the more efficacious a participant is, the more challenging goals are set. Goal-setting in turn affects the academic performance and the efforts exerted into the tasks. Therefore, to perfect the achievement, the intensity of self-efficacy cannot be ignored. As for the influences of self-efficacy on self-regulatory strategies, the statistics result shows that there is no direct connection between participants' self-efficacy and the use of self-regulatory strategies. However, with the mediators of goal-setting and intended efforts, the strength of self-efficacy indirectly associated with self-regulatory strategies. Only after the participants clearly hold their personal belief in their ability do they set concise goals and put into considerable efforts to carry out the strategies in order to accomplish the academic tasks.

The role of goal setting:

In the present study, Goal setting positively correlates with self-regulatory strategies, intended effort, and achievement. This result is consistent with previous studies (Fu, 2011; Mukherjee, 1965; Wang \& Zhang, 2010). Goal-setting is a prerequisite of self-regulatory strategies in that setting goals involves a lot of metacognitive, and cognitive approach. For example, the student needs to gauge personal ability and then decide how much effort and time be dedicated to achieving the goals. The approach, or strategies, parallel the innate traits of self-regulatory strategies. Some research even indicates that a portion of self-regulation includes learning how to make proximal goals in order to accomplish more distal ones (Bandura \& Schunk, 1981; Zimmerman, 2000).

To achieve the goals, intended efforts should be exerted to ensure the results. For example, the students need to spend some time studying the subject English. With the strategies and efforts, the learners can improve their performance and achieve their goals. These variables are closely correlated with each other.

For the participants in the present study, they need the teachers' guidance to set their learning objectives. In the process of setting goals, the participants can better understand their inner thoughts and underlying potentials. The goals should be set for short-term use, because learners' need and motivation are dynamic. The outlying factors may have an influence on learners' goals. The goals need to be modified after a certain period of time in order to fit the learners' real situation. With the change of the goals, the strategies to accomplish the task should be reorganized. The cognitive, meta-cognitive, emotional, environmental and other strategies should be modified as well. For example, the learners should overcome the feeling of abandoning or frustration. They also need to reconsider and reorganize their study plan. On the other hand, though the short-term goals are reset and revise from time to time, the overall long-term goal needs to be stable so that the learners can have a definite aim and strong determination to reach the overall long-term goal. Through the interaction of self-regulatory mechanism and goal-setting process, the learners can make better performance in academic achievement.

\section{Implication and conclusion}

This study aims at constructing a model to evaluate the causal relationship among the following variables: self-efficacy, L2 anxiety, goal-setting, self-regulatory strategies and their influences on academic performance. The statistical results of the final model indicate the model is a suitable model that can adequately explains the interrelationship between all the latent variables for the language learners in Taiwan. The L2 anxiety functions as the predictor of self-efficacy, goal-setting, and self-regulatory strategies. The more anxious a second language learner gets, the lower self-efficacy the learner possesses. The more anxiety a language learner senses, the less challenging goals are set, and the fewer strategies employed to accomplish academic requirements. The goals the learner sets influence the strategies used, and also influences the efforts put into the task. To encourage the learners to set the learning objectives can help them improve their academic performance. However, the intensity 
of anxiety needs to be reduced so that the level of self-efficacy can be elevated and then challenging goals can be set. With specific goals being set, intended efforts can be instilled and self-regulatory strategies can be used to accomplish the complex academic tasks.

The limitation is that the sample is selected from one senior high school, the results may not be able to be generalized across the EFL context. The eventual objective of teaching is to lead the learners to learn independently. With the exploration of the interrelationship of the individual differences, the educators can have a deeper insight of the learners' inner selves.

\section{References}

Aida, Y. (1994). Examination of Horwitz, Horwitz, and Cope's Construct of Foreign Language Anxiety: The Case of Students of Japanese. The Modern Language Journal, 78(2), 155-168. https://doi.org/10.1111/j.1540-4781.1994.tb02026.x

Bailey, P., Onwuegbuzie, A. J., \& Daley, C. E. (1999). Foreign language anxiety and learning style. Foreign Language Annals, 32(1), 63-76. https://doi.org/10.1111/j.1944-9720.1999.tb02376.x

Bandura, A. (1977). Self-efficacy: Toward a unifying theory of behavioral change. Psychological Review, 84(2), 191-215. https://doi.org/10.1037/0033-295X.84.2.191

Bandura, A. (1986). The explanatory and predictive scope of self-efficacy theory. Journal of Clinical and Social Psychology, 4, 359-373. https://doi.org/10.1521/jscp.1986.4.3.359

Bandura, A. (1993). Perceived self-efficacy in cognitive development and functioning. Educational Psychologist, 28(2), 117-148. https://doi.org/10.1207/s15326985ep2802_3

Bandura, A. (1994). Self-efficacy. In V. S. Ramachaudran (Ed.), Encyclopedia of human behavior (Vol. 4, pp. 71-81). New York: Academic Press.

Bandura, A. (1997). Self-efficacy: The exercise of control. New York: Freeman.

Brown, S. P., Jones, E., \& Leigh, T. W. (2005). The attenuating effect of role overload on relationships linking self-efficacy and goal level to work performance. Journal of Applied Psychology, 90, 972-979. https://doi.org/10.1037/0021-9010.90.5.972

Carroll, A., Gordon, K., Haynes, M., \& Houghton, S. (2013). Goal setting and self-efficacy among delinquent, at-risk and not at-risk adolescents. Journal of Youth and Adolescence, 42(3), 431-443.

Cheung, W. M., \& Cheng, Y. C. (1997). A multi-level analysis of teachers'self-belief and behavior, and student's educational outcomes. Paper presented at the annual meeting of the American Educational Research Association, Chicago.

Clement, R. (1980). Ethnicity, contact, and communicative competence in a second language. In H. Giles, W. P. Robinson, \& P. M. Smith (Eds.), Language: Social psychological perspectives (pp. 147-154). Oxford, United Kingdom: Pergamon Press.

Corno, L., \& Kanfer, R. (1993). The role of volition in learning and performance. In L. D. Hmmond (Ed.), Review of Research in Education (Vol. 21, pp. 301-341). Itasca, IL: F.E. Peacock Publishers. https://doi.org/10.2307/1167345

Dörnyei, Z. (2001). Motivational Strategies in the Language Classroom. Cambridge: Cambridge University Press. https://doi.org/10.1017/CBO9780511667343

Dörnyei, Z. (2005). The psychology of the language learner: Individual differences in second language acquisition. Mahwah, NJ: Lawrence Erlbaum.

Dörnyei, Z., \& Skehan, P. (2003). Individual differences in second language learning. In C. J. Doughty, \& M. H. Long (Eds.), The handbook of second language acquisition (pp. 589-630). Oxford: Blackwell. https://doi.org/10.1002/9780470756492.ch18

Ellis, R. (1994). The Study of Second Language Acquisition. Oxford, UK: Oxford University Press.

$\mathrm{Fu}$, J. (2011). The relationships among self-efficacy, achievement motivation, and work values for regular four-year university students and community college students in china. Retrieved from http://hdl.handle.net/2142/26040

Gardner, R.C., Tremblay, P.F., \& Masgoret, A.M. (1997). Toward a full model of second language learning: an empirical investigation. The Modern Language Journal, 81(3), 344-362. https://doi.org/10.1111/j.1540-4781.1997.tb05495.x 
Horwitz, E. K. (2010). Foreign and second language anxiety. Language Teaching, 43, 154-167. https://doi.org/10.1017/S026144480999036X

Horwitz, E. K. (2001). Language anxiety and achievement. Annual Review of Applied Linguistics, 21, 112-126. https://doi.org/10.1017/S0267190501000071

Horwitz, M. B., Horwitz, E. K., \& Cope, J. A. (1986). Foreign language classroom anxiety. The Modern Language Journal, 70(2), 125-132. https://doi.org/10.1111/j.1540-4781.1986.tb05256.x

Kormos, J. \& Csizer, K. (2014). The interaction of motivation, self-regulatory strategies, and autonomous learning behavior in different learner groups. TESOL Quarterly, 48(2), 275-299. https://doi.org/10.1002/tesq.129

Kuhl, J. (1985). Volitional mediators of cognition-behavior consistency: Self-regulatory processes and action versus state orientation. In J. Kuhl \& J. Beckmann (Eds.), Action control: From cognition to behavior (pp. 101-128). Berlin, Germany: Springer. https://doi.org/10.1007/978-3-642-69746-3_6

Liu, M. (2006). Anxiety in EFL classrooms: Causes and consequences. TESL Reporter, 39(1), 13-32.

Liu, M., \& Huang, W. (2011). An exploration of foreign language anxiety and English learning motivation. Education Research International, 1, 1-8. https://doi.org/10.1155/2011/493167

Locke, E. A. (1968). Towards a theory of task motivation and incentives. Organizational Behavior and Human Performance, 3, 157-189. https://doi.org/10.1016/0030-5073(68)90004-4

Locke, E. A., \& Latham, G. P. (1990). A theory of goal setting and task performance. Englewood Cliffs, NJ: Prentice-Hall.

Locke, E. A., \& Latham, G. P. (2006). New directions in goal-setting theory. Current Directions in Psychological Science, 15(5), 265-268. https://doi.org/10.1111/j.1467-8721.2006.00449.x

MacIntyre, P. (1999). Language anxiety: A review of the research for language teachers. In D. J. Young (Ed.), Affect in foreign language and second language learning. A practical guide to creating a low-anxiety classroom atmosphere (pp. 13-23). Boston: McGraw-Hill.

MacIntyre, P. D., \& Gardner, R. C. (1989). Anxiety and second language learning: toward a theoretical clarification. Language Learning, 39(2), 251-275. https://doi.org/10.1111/j.1467-1770.1989.tb00423.x

MacIntyre, P., \& Gardner, R. (1994). The subtle effects of language anxiety on cognitive processing in the second language. Language Learning, 44, 283-305. https://doi.org/10.1111/j.1467-1770.1994.tb01103.x

MacIntyre, P., Noels, K., \& Clement, R. (1997). Biases of self-ratings of second language proficiency: The role of language anxiety. Language Learning, 47, 265-287. https://doi.org/10.1111/0023-8333.81997008

Mukherjee, B. (1965). Achievement motivation and goal-setting behavior in the classroom. British Journal of Educational Psychology, 33(3), 286-293. https://doi.org/10.1111/j.2044-8279.1965.tb01816.x

O’Malley, J., \& Chamot, A. (1990). Learning strategies in second language acquisition. Cambridge, England: Cambridge University Press. https://doi.org/10.1017/CBO9781139524490

Oxford, R. (1999). Anxiety and the language learner: New insights. In J. Arnold (Ed.), Affect in language learning (pp. 58-67). Cambridge, United Kingdom: Cambridge University Press.

Pajares, F., \& Urdan, T. (Eds.). (2006). Self-efficacy beliefs of adolescents. Greenwich, CT: Information Age Publishing.

Papi, M. (2010). The L2 Motivational Self System, L2 anxiety, and motivated behavior: A structural equation modeling approach. System, 38(3), 467-479. https://doi.org/10.1016/j.system.2010.06.011

Piniel, K. \& Csizer, K. (2013). L2 motivation, anxiety and self-efficacy: The interrelationship of individual variables in the secondary school context. Studies in Second Language Learning and Teaching, 3(4), 523-550. https://doi.org/10.14746/ssllt.2013.3.4.5

Pintrich, P. R. (2004). A conceptual framework for assessing motivation and self-regulated learning in college students. Educational Psychology Review, 16(4), 385-407. https://doi.org/10.1007/s10648-004-0006-x

Pintrich, P. R., and De Groot, E. V. (1990). Motivational and self-regulated learning components of classroom academic performance. Educational Psychology, 82, 33-40. https://doi.org/10.1037/0022-0663.82.1.33

Reeve, J., Ryan, R., Deci, E. L., \& Jang, H. (2008). Understanding and promoting autonomous self-regulation: A self-determination theory perspective. In D. H. Schunk, \& B. J. Zimmerman (Eds.), Motivation and 
self-regulated learning: Theory, research and applications (pp. 223-244). New York, NY: Lawrence Erlbaum.

Rodríguez, M., \& Abreu, O. (2003). The stability of general foreign language classroom anxiety across English and French. The Modern Language Journal, 87(3), 365-374. https://doi.org/10.1111/1540-4781.00195

Schunk, D. H. (1991). Goal setting and self-evaluation: A social cognitive perspective on self-regulation. In M. L. Maehr, \& P. R. Pintrich (Eds.), Advances in motivation and achievement, Vol. 7 (pp. 85-113). Greenwich, CT: JAI Press.

Schunk, D. H. (1995). Self-efficacy and education and instruction. In J. E. Maddux (Ed.), Self-efficacy, adaptation, and adjustment: Theory, research, and application (pp. 281-303). New York: Plenum Press. https://doi.org/10.1007/978-1-4419-6868-5_10

Schunk, D. H., \& Zimmerman, B. J. (1997). Social origins of self-regulatory competence. Educational Psychologist, 32, 195-208. https://doi.org/10.1207/s15326985ep3204_1

Scovel, T. (1978). The effect of affect on foreign language learning: A review of the anxiety research. Language Learning, 28, 129-142. https://doi.org/10.1111/j.1467-1770.1978.tb00309.x

Skehan, P. (1989). Individual differences in second language acquisition. Hodder Education.

Sparks, R. L., \& Ganschow, L. (1996). Teachers' perceptions of students' foreign language academic skills and affective characteristics. The Journal of Educational Research, 89(3), 172-185. https://doi.org/10.1080/00220671.1996.9941323

Sparks, R., \& Ganschow, L. (1991). Foreign language learning differences: Affective or native language aptitude differences? The Modern Language Journal, 75, 3-16. https://doi.org/10.1111/j.1540-4781.1991.tb01076.x

Sparks, R., \& Ganschow, L. (2007). Is the Foreign Language Classroom Anxiety Scale (FLCAS) measuring anxiety or language skills? Foreign Language Annals, 40, 260-287. https://doi.org/10.1111/j.1944-9720.2007.tb03201.x

Spielberger, C. D. (1983). Manual for the state-trait anxiety inventory (Form Y). Palo Alto, CA: Consulting Psychologists Press.

Taguchi, T., Magid, M., \& Papi, M., (2009). The L2 motivational self system amongst Chinese, Japanese, and Iranian learners of English: a comparative study. In Z. Dörnyei, \& E. Ushioda (Eds.), Motivation, Language Identity and the L2 Self. Multilingual Matters, Clevedon (pp. 66-97). https://doi.org/10.21832/9781847691293-005

Tseng, W., \& Schmitt, N. (2008). Toward a model of motivated vocabulary learning: A structural equation modeling approach. Language Learning, 58(2), 357-400. https://doi.org/10.1111/j.1467-9922.2008.00444.x

Tseng, W., Dörnyei, Z., \& Schmidt, N. (2006). A new approach to assessing strategic learning: the case of self-regulation in vocabulary acquisition. Applied Linguistics, 27(1), 78-102. https://doi.org/10.1093/applin/ami046

Tseng, W., Liu, H., \& Nix, J. (2017). Self-regulation in language learning: Scale validation and gender effects. Perceptual and Motor Skills, 124(2), 531-548. https://doi.org/10.1177/0031512516684293

Usher, E. (2009). Sources of middle school students' self-efficacy in mathematics: A qualitative investigation. American Educational Research Journal, 46, 275-314. https://doi.org/10.3102/0002831208324517

Usher, E. L., \& Pajares, F. (2008). Sources of self-efficacy in school: Critical review of the literature and future directions. Review of Educational Research, 78, 751-796. https://doi.org/10.3102/0034654308321456

Wang, J., \& Zhang, Q. (2010). The relationship between career decision-making self-efficacy and achievement motivation of college students. Ludong University Journal (Philosophy and Social Sciences Edition), 27(2), 90-93.

Winne P. H. (1996). A metacognitive view of individual differences in self-regulated learning. Learning and Individual Differences, 8(4), 327-353. https://doi.org/10.1016/S1041-6080(96)90022-9

Winne, P., and Perry, N. (2000). Measuring self-regulated learning. In M. Boekaerts, P. R. Pintrich, \& M. Zeidner (Eds.), Handbook of Self-Regulation. Academic Press, San Diego, CA (pp. 531-566). https://doi.org/10.1016/B978-012109890-2/50045-7

Young, D. J. (1992). Language anxiety from the foreign language specialist's perspective: Interviews with Krashen, Omaggio-Hadley, Terrell, and Rardin. Foreign Language Annals, 25, 157-172. 
https://doi.org/10.1111/j.1944-9720.1992.tb00524.x

Zhang, L. J. (2001). Exploring variability in language anxiety: Two groups of PRC students learning ESL in Singapore. RELC Journal, 32(1), 73-94. https://doi.org/10.1177/003368820103200105

Zimmerman, B. J. (1998). Academic studying and the development of personal skill: A self-regulatory perspective. Educational Psychology, 33, 73-86. https://doi.org/10.1080/00461520.1998.9653292

Zimmerman, B. J. (2000). Attaining self-regulation: A social cognitive perspective. In M. Boekaerts, P. R. Pintrich, \& M. Zeidner (Eds.), Handbook of self-regulation (pp. 13-39). San Diego, CA: Academic Press. https://doi.org/10.1016/B978-012109890-2/50031-7

\section{Copyrights}

Copyright for this article is retained by the author(s), with first publication rights granted to the journal.

This is an open-access article distributed under the terms and conditions of the Creative Commons Attribution license (http://creativecommons.org/licenses/by/4.0/). 